\title{
DEVELOPMENT OF MASSIVE OPEN ONLINE COURSE (MOOC) BASED ON ADDIE MODEL FOR CATERING COURSES
}

\author{
Mohd Erfy Ismail \\ Universiti Tun Hussein Onn Malaysia \\ erfy@uthm.edu.my \\ Pipit Utami \\ Universitas Negeri Yogyakarta \\ pipitutami@uny.ac.id \\ Irwan Mahazir Ismail \\ Universiti Tun Hussein Onn Malaysia \\ irwanm@uthm.edu.my \\ Norhasyimah Hamzah \\ Universiti Tun Hussein Onn Malaysia \\ hasyimah@uthm.edu.my \\ Hairuddin Harun \\ Universiti Tun Hussein Onn Malaysia \\ hairuddin@uthm.edu.my
}

\begin{abstract}
Nowadays, innovation for teaching aids is an important requirement to ensure the teaching and learning process can run smoothly. Coinciding with the Malaysia Education Blueprint 2013-2025 (Ministry of Education) through the ninth surge of Global Online Learning, the development of the Massive Open Online Course (MOOC) was built. The ADDIE model has been adapted for this development. The study aims to develop an appropriate interactive learning for Food and Beverage Presentation subjects based on the Vocational College (VC) syllabus. In research development, researchers use Richey and Klein research recommendations, using Alpha and Beta tests in the evaluation phase of the study. The population of the study involved 155 Catering students at Muar Vocational College and the sample of the study were 60 of third and fourth-year Diploma students. The sampling method used is the purposive sampling and the instrument used in the form of the questionnaire. Data collected were collected and analyzed descriptively using Statistical Packages for Social Science (SPSS) version 23.0. Based on the analysis, the reliability value of the instrument is 0.997 and shows that the reliability of the instrument is at a high level. The findings show that the use of MOOC can increase computer literacy (3.75), interest (3.78) and student learning styles (3.75) and make the learning process more interesting. In addition, the findings show that the use of the MOOC application can help students in improving the performance and achievement of students in learning and thus can be an alternative to diversifying the teaching and learning process in VC.
\end{abstract}

Keywords: MOOC Literacy, Interest, Learning Style, ADDIE Model, Catering, TVET 


\section{INTRODUCTION}

Technical \& Vocational Education and Training (TVET) Malaysia has been empowered by Ministry of Higher Education (MOHE) of Malaysia to improve the image and quality of Malaysia TVET education towards World Class Education (Minghat, Yasin, Subari, \& Noordin, 2013). TVET aims to develop students' skills, abilities, and understanding of real-world employment and prepare skilled manpower for future use (Aziz, Ramli, \& Othman, 2014). According to Osman (2016), through Technical and Vocational Education, the skills majors can contribute to a knowledge-based economy, technology and mobility of the workforce. Students who want to continue their studies towards skills-based education, they can choose the vocational college to understand, learn and explore the skills there.

Information and computer technology greatly influences the lives of society today. The emergence of computer technology and modern communication tools can help people to collect, process and handle information easily and systematically (Anggraini, Mukhadis, \& Muladi, 2013). Teachers are now encouraged in computer literacy so that knowledge in the 21st century can be explored and utilized in the $\mathrm{P} \& \mathrm{P}$ process (Penny, Friston, Ashburner, Kiebel, \& Nichols, 2011). The use of computers is increasingly important in everyday life, whether in the office or at home. Vision 2020 faces the challenges of life-based on science and technology as one of the key agenda (I. M. Bin Ismail, 2005). One of the implementation of ICT in learning is electronic learning (Priyanto, Sofyan, \& Surjono, 2017). Utilization of the Internet in the form of web-based learning media is one form of e-learning which in this era is popularly developed by various educational institutions (Hardyanto \& Surjono, 2016).

Online learning with the valid and structured material is important for students in the achievement of learning objectives Prastiyo, Djohar, \& Purnawan (2018). MOOC is an online learning course whose participants are unlimited and can be accessed openly through the website. According to Aris \& Halim (2016), Massive Open Online Course (MOOC) is an online course aimed at massive interactive participation and open access through web- sites. MOOC is an online learning accessible to everyone around the globe for free (Kop \& Carroll, 2011). MOOC is a global online learning capable of accommodating student capacity on a large scale (Nordin, Norman, \& Embi, 2016). In fact, the field of skills is an important field especially for developing countries to prepare for the 21st century (Bakar \& Latif, 2010).

Not only that, Abidin (2014) stated that attitude or interest in teaching and learning process could be embedded in digital literacy practices for all academic institutions to support the concept of e-learning as an effective learning method. Additionally, this is in line with the needs of the country's e-learning policy and 21 st-century education that highlights student-centered learning.

Based on the background of the problem, a new culture in ICT or e-learning is one of the effective teaching approaches and can help teachers by diversifying teaching methods to facilitate students to understand while helping teachers to carry out their teaching smoothly and in order. Additionally, teachers can achieve outstanding student achievement and create their success much easier (Abdullah, 2010). This new development has created a new flexible learning environment in terms of time, place, method and learning materials (Othman \& Mohamad, 2014). They need to act and react to explore these interactive and digital methods in learning (Gan, Menkhoff, \& Smith, 2015).

The use of the MOOC especially among academics helps increase the motiva-tion and interest among students who are still fading in e-learning (Yahya, 2013). The world is growing in e-learning. Thus, this learning allows students to learn anywhere and at the time chosen by the students. This allows students to manage their own time more effectively. This virtual learning also involves the use of optimal costs. In addition, interactive learning styles online allow students to explore new information through digital libraries or websites (Pappano, 2012). Therefore, students can work in groups or individually to view and collect information, analyze and evaluate information obtained directly through an e-learning platform. As more and more technologies are introduced in the field of education, this treasure of knowledge can provide and disseminate information and knowledge globally. 
The objective of this study is to study the following: (a) develop MOOC platform for use in learning; (b) to test the functionality of using the MOOC learning platform; (c) MOOC literacy among students towards MOOC usage; (d) the interests of students towards MOOC usage; (e) the student learning styles towards MOOC usage.

\section{METHODOLOGY}

In the research development, this research was used Richey \& Klein (2014) development design, which uses Alpha and Beta testing in the evaluation phase of the study that software or products developed should apply appropriate models to help students solve problems and improve student performance. This product uses product development design. The model used to design this project is ADDIE Model. According to Richey \& Klein (2014), there are five (5) phases in this model is analysis phase, design phase, development phase, implementation phase and evaluation phase. This model was chosen based on the approach to the development of the study by solving the problems arising from the early stages.

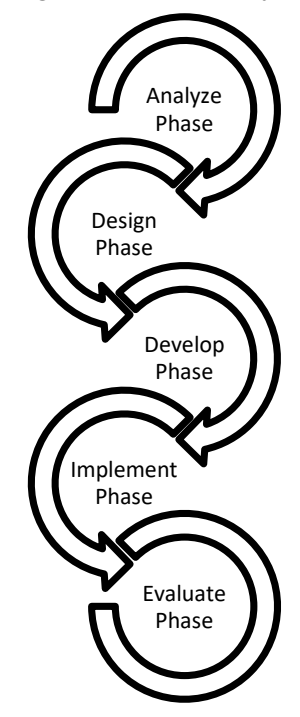

Figure 1. ADDIE Model

\section{Analysis Phase}

At this stage, the analysis phase involves several determining processes and identifies the problems that need to be resolved. After a problem can be identified an analytical process will be carried out to find out what causes or factors are related or that cause the problem. The analysis process covers the problems faced, product requirements include the objective of developing the product (Halim et al., 2012). In addition, the phase of analysis is the basis of all phases in this instructional design model. To develop the MOOC for catering programs at the Muar Vocational College, researchers have set some research objectives as in 1.4. Based on the objective of the study, researchers need to design an interactive learning through the MOOC, develop it as one of the $\mathrm{ABBM}$ and test the level of flexibility in its use in learning. During this phase, the researcher set user targets for the development of this MOOC. Among the main focus of the target are educators in catering and respondents for this study which consists of students of catering programs, especially Vocational College of Muar, Johor.

\section{Design Phase}

At this stage of the process, it explains the overall view of the design, structure, teaching approaches, types of media and technologies to be used, content and script/storyboard. This phase is crucial for planning strategies in developing teaching and outlining how to achieve teaching goals.Development needs to acquire appropriate learning objectives and it should be based on the use of learning materials in Vocational Collage according to the prescribed syllabus. In addition to learning notes, the design of activities, training and quizzes/tests should also be developed. According to Lee, Hsieh, \& Hsu (2011), development should be appropriate and check the way or method of delivery of information in the software to be more user-friendly. Among the things that need to be emphasized in this design phase are content design and script/storyboard design.

\section{Development Phase}

This stage involves real system implementation by using all appropriate media and technology elements based on requirements. Built based on analysis and design phase. The purpose of this phase is to produce lesson plans and learning materials (Davis, 2013). During this phase will be developed, the teaching steps as well as the media to be used in teaching and other required documents. According to Hishamuddin (1987), the output in the design phase will be input to the development phase. The 
multimedia project development work will be done according to the agreed-upon specifications. Each development will be tested to ensure that it is consistent and effective.

\section{Implement Phase}

At this stage, the teaching materials that have been prepared will be used or implemented in real terms. In this phase, testing was also made. Testing will be made on MOOC which will be developed by the researcher. The completed MOOC development project will be tested on users to identify errors during the project development process. In the event of a mistake, the repair will be made before it is fully delivered to the target user for use. All syllabus, activities, discus-sions, references, and notes will be included in the MOOC platform at https://www.openlearning.com/ in stages.

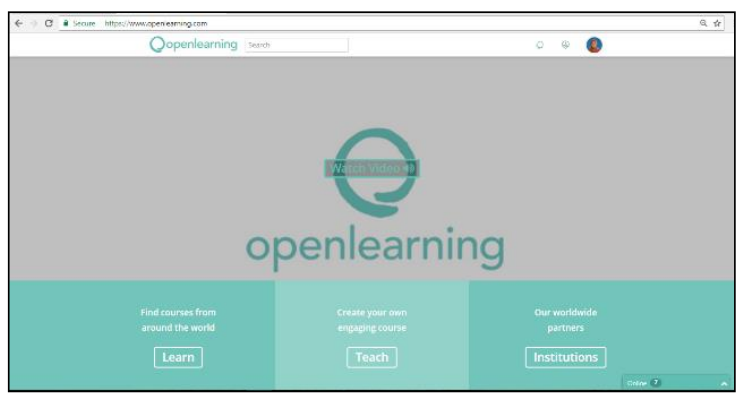

Figure 2. Open Learning

\section{Evaluate Phase}

This phase is an advanced phase of the implementation phase. This phase is evaluated from two aspects of assessment, namely (i) usability assessment, and (ii) conformity assessment (Nordin et al., 2016). Instead, the main purpose of this phase is to detect weaknesses and failures in the development process and operating system. As such, three experts comprising MOOC specialists, multimedia specialists and technical and vocational (catering) experts to evaluate and verify MOOC functionality developed through the expert confirmation form to be provided. Additionally, the usability of MOOC development was assessed through a questionnaire given to 60 students.

\section{Population and Sample Study}

According to Thomas et al. (2010), the population is the target group of researchers in which the group to whom the results will be generalized. The population in this study involved 155 students taking a catering program at Muar Vocational College. The sampling was the respondents selected to represent a population (Goodman, 2011). The sampling method that used is was purposive sampling which is consists of third year and fourth-year students taking the Diploma in Catering Arts of 60 who took the subject of Food and Beverage Presentation

\section{Validity and Reliability of Instruments}

Validity and reliability are important to ensure that the findings are credible and unquestionable (Csikszentmihalyi \& Larson, 2014). To ensure that the questionnaire can be used, the validity must be made first. The validity used in the study is the validity of the content and the validity of multimedia. The researcher has obtained three experts to determine the validity of the questionnaire which has been developed. The three experts consisted of a MOOC expert, a multimedia expert, and professor in vocational education (catering).

The reliability of the instrument is a measure to determine the consistency of the score against each item found in the questionnaire form. This is to preserve the accuracy of the questionnaire instrument from having any problems and data obtained accurately. To see the reliability of the questionnaire, an internal methodology was used Cronbach Alpha method. Based on the analysis that has been made, Alpha Cronbach's value is 0.997 and is at a high level (Ghafar, 2003).

All the items in the questionnaire were analyzed by appraising using four-point Likert scale scores based on a very disagreeing, disagreeing, agreeing and strongly agreeing. Item analysis refers to the range of mean scores such as Table 1 which determines the level of respondents' stance on items in question.

Table 1. Mean Score Analysis

\begin{tabular}{cc}
\hline Mean & Level \\
\hline $1.00-2.33$ & Low \\
$2.34-3.66$ & Moderate \\
$3.67-5.00$ & High \\
\hline
\end{tabular}

\section{MOOC Literacy Analysis}

Table 2. shows the results of MOOC literacy which is the respondents involved in 
the questionnaire by item and finds the mean result obtained is moderate and it clearly indicates that respondents agree with this item. This shows the respondents' decision to answer the first question is positive and computer literacy among catering is good.

Table 2. Data Analysis of MOOC Literacy

\begin{tabular}{clcc}
\hline No & \multicolumn{1}{c}{ Item } & Mean & SD \\
\hline B1. $\begin{array}{l}\text { I understand more about } \\
\text { learning when using MOOC. }\end{array}$ & 3.63 & 0.486 \\
B2. $\begin{array}{l}\text { I know how to use the MOOC } \\
\text { learning platform. }\end{array}$ & 3.68 & 0.469 \\
B3. $\begin{array}{l}\text { I am more likely to find infor- } \\
\text { mation through MOOC's } \\
\text { learning platform. }\end{array}$ & 3.68 & 0.469 \\
B4. $\begin{array}{l}\text { I'm more interested in learning } \\
\text { to use MOOC than books. }\end{array}$ & 3.55 & 0.502 \\
B5. $\begin{array}{l}\text { I feel the MOOC application } \\
\text { helps me practice SLT (Self } \\
\text { Learning Time) }\end{array}$ & 3.65 & 0.481 \\
B6. $\begin{array}{l}\text { I am experienced in controll- } \\
\text { ing the MOOC platform. } \\
\text { The information provided in } \\
\text { the MOOC platform is clearly } \\
\text { communicated. }\end{array}$ & 3.67 & 0.51 \\
B8. & $\begin{array}{l}\text { MOOC can help improve my } \\
\text { academic achievement. }\end{array}$ & 3.75 & 0.446 \\
\hline
\end{tabular}

\section{Students Interest Analysis}

Table 3. shows the results of students interest towards MOOC usage. The results found that the majority respondents strongly agreed on the items given and this clearly showed that students interest in the use of MOOC for learning was high.

Table 3. Data Analysis of Students Interest

\begin{tabular}{|c|c|c|c|}
\hline No & Item & Mean & $\mathrm{SD}$ \\
\hline C1. & $\begin{array}{l}\text { I love learning to use the } \\
\text { MOOC learning platform. }\end{array}$ & 3.7 & 0.462 \\
\hline $\mathrm{C} 2$. & $\begin{array}{l}\text { I like it when teachers use } \\
\text { MOOC as a teaching aids tool. }\end{array}$ & 3.78 & 0.415 \\
\hline C3. & $\begin{array}{l}\text { I love to answer the questions in } \\
\text { the MOOC. }\end{array}$ & 3.73 & 0.446 \\
\hline C4. & $\begin{array}{l}\text { I use MOOC's learning platform } \\
\text { for all subjects. }\end{array}$ & 3.72 & 0.454 \\
\hline C5. & $\begin{array}{l}\text { I am ready to use the } \mathrm{MOOC} \text { at } \\
\text { any time. }\end{array}$ & 3.73 & 0.446 \\
\hline C6. & $\begin{array}{l}\text { I always take the opportunity to } \\
\text { learn using MOOC. }\end{array}$ & 3.67 & 0.475 \\
\hline C7. & $\begin{array}{l}\text { I often use MOOC to get } \\
\text { learning materials. }\end{array}$ & 3.68 & 0.469 \\
\hline C8. & $\begin{array}{l}\text { I feel the convenience in } \\
\text { MOOC stimulates my learning. }\end{array}$ & 3.73 & 0.446 \\
\hline
\end{tabular}

\section{Student Learning Style}

Table 4. shows the results of the students learning style using MOOC. The results found that the majority respondents strongly agreed on the items given and this clearly showed that students learning styles while using MOOC for learning was high.

Table 4. Data Analysis of Student Learning Style

\begin{tabular}{cccc}
\hline No & \multicolumn{1}{c}{ Item } & Mean & SD \\
\hline D1. $\begin{array}{l}\text { I often visit MOOC's website to } \\
\text { find information. }\end{array}$ & 3.7 & 0.462 \\
D2. $\begin{array}{l}\text { MOOC helped me learn not to } \\
\text { think time }\end{array}$ & 3.75 & 0.437 \\
D3. $\begin{array}{l}\text { I use the MOOC learning } \\
\text { platform in daily tasks. }\end{array}$ & 3.68 & 0.469 \\
D4. $\begin{array}{l}\text { Information is easier to obtain } \\
\text { when using the MOOC app. }\end{array}$ & 3.7 & 0.462 \\
D5. $\begin{array}{l}\text { I love to use MOOC applications } \\
\text { in helping the learning process. }\end{array}$ & 3.67 & 0.475 \\
D6. $\begin{array}{l}\text { The MOOC app helped me to } \\
\text { understand something learning. }\end{array}$ & 3.67 & 0.475 \\
D7. $\begin{array}{l}\text { I always invite my friends to join } \\
\text { the MOOC app. }\end{array}$ & 3.72 & 0.454 \\
D8. $\begin{array}{l}\text { I love to learn to use the materials } \\
\text { on the MOOC platform }\end{array}$ & 3.72 & 0.454 \\
\hline
\end{tabular}

\section{DISCUSSION}

The findings of this study show that computer literacy among catering students on MOOC application in VC Muar is at the moderate level for the whole item. This can be seen when some students agree that they know how to use the MOOC platform. According to Arsyad (2011), online e-learning sessions with computers are very easy to update as the latest content can be uploaded or downloaded to a user's computer. The findings also show that some students feel that MOOC's application helps them to practice self-learning time besides the information provided in the MOOC platform is presented clearly. Mohamad \& Shariff, 2011) in their study found that online members involved in discussions and interacting effectively can set the tasks that are appropriate for them.

Besides, findings shows that some students agree that they understand more about learning when using this application. In online interaction, students are more interested in learning to use the MOOC platform than scientific books. This is supported by Manaf et al. (2015) student interaction with MOOC app is the kind of interaction between student and 
interface. This is because the MOOC app makes it easier and more user-friendly because students and other users can access unlimited limits.

An interaction between students and the interface is very important because the on-line and easy-to-use interface of learning can attract students to actively participate in online learning (Manaf et al., 2015). Students are de-lighted and comfortable using computers and therefore they are more likely to seek information through the MOOC learning platform. It can be explained that multimedia has the potential to create a high-quality learning envi-ronment, with the ability to create more realis-tic learning contexts through different media (Nusir, Alsmadi, Al-Kabi, \& Sharadgah, 2012).

With the rapid technology and sophisticated facilities provided in our country's institutions, it is extremely costly if not applied to multimedia elements especially the use of computers and MOOC for learning (Ismail et al., 2018). In conclusion, student acceptance of MOOC literacy is at a moderate level but needs to be improved to ensure the smooth implementation of the course using the MOOC application. The results of the analysis obtained from questions 1 to 8 have answered this question.

Moreover, this research found that the students intereted when the teacher used MOOC as teaching aids. Then, the researcher found that the use of MOOC in the teaching and learning process in the classroom was one of the teaching aids that helped the teacher to increase the interest and performance of students in a subject (Sharif, 2012). Not only that, students also love to use this platform for learning. This is reinforced by Hew (2016) Brundiers and Wiek (2010), which states the use of MOOC in the learning process allows the classroom to meet the real world and enable students to find original information and materials, facilitating collaborative and facilitating multimedia materials to be easily created and disseminated.

Furthermore, students are ready to use the MOOC platform at any time. Thus, seeking information and teaching and learning materials via the internet or the website not only helps to increase the use of multimedia in diversifying multimedia facilities among teachers but also involving students to make the Internet a source of reference (Suryadi,
2007). From the perspective of students, internet usage and websites like the use of MOOC can encourage students to take advantage of learning using MOOC.

According to Ibrahim (2015), students should have shown high interest in classes using the website because it is easy to get information directly. Furthermore, students can ask questions and provide answers at any time and they can complete the training and assignments according to their own ability and suitability (MdYusof, 2014). Additionally, the increased interest in the students peaked when the information contained in the website from various levels of course and general allows students to be free to choose the appropriate information according to their level of understanding and ability (Arsyad, 2008). Karsidi (2013) stated that multimedia technology like MOOC has paved the way for new education. For example, drilling strategies where some attempts have to be made by the students. Learning using MOOC can provide immediate feedback to students. This will indirectly give a very positive reinforcement to the students' interest.

The results of the analysis obtained from questions 1 to 8 have answered the question of this study. In this regard, the researchers can conclude and argue that the student's interest in using MOOC is at a high level. Researchers argue that most items of student interest questions on MOOC use among catering students have shown that students are aware of the MOOC application facility in the learning process. This is in line with Bell's (2010) statement, through the multimedia software that is the use of MOOC, students are also more likely to understand and work to improve their mastery of the concepts they are teaching.

The findings show that catering students' styles in MOOC use are at high levels for the whole item. This can be seen when some students agree that they visit the MOOC's website to find information materials. Motivation in determining the learning style of learning is the overall ability to move someone who helps the learning method to ensure the learning technique so that the purpose of the individual or subject of learning can be achieved (Williams \& Williams, 2011). Schunk, Meece, \& Pintrich (2013), described that learning styles are very complex that can refer to the term acceptance of someone who characterizes 
the existence of feelings and reactions. This can be seen when some students agree that the MOOC helps them learn not to spend time. This statement is supported by Vaibhav \& Gupta (2014), where MOOC users can access without any time and place gaps. In addition, the findings show that stu-dents use the MOOC platform on daily basis. This statement is reinforced by (Tessier, Sarra-zin, \& Ntoumanis (2010) through multimedia learning software that has the graphic, anima-tion, audio and video elements that can provide motivation for learning, as well as providing more effective and complete explanations.

The findings of the next study show individual and group learning preferences driven by MOOC's use. The findings also show MOOC's application to help students choose the content of the lesson creatively as well as the desire to seek higher knowledge. According to Yahya (2013), students are increasingly likely to find the information needed through electronic-based facilities arising from the widespread dissemination of information. Multimedia technology has vast potential to improve the quality and efficiency of the learning process with critical and creative (Insyasiska, Zubaidah, \& Susilo, 2015). In conclusion, student learning styles in MOOC use are high but need to be improved to ensure MOOC implementation among catering students. Results of the analysis obtained from questions 1 through 8 have answered the question of this study.

\section{CONCLUSION}

The findings provide information to researchers on the importance of using MOOC in the teaching and learning process, especially for catering program at Muar Vocational College. Besides, the MOOC literacy, student interest and learning style towards MOOC usage can enhance by using effective methods which can ensure the maximum level of learning of the students in addition to ensuring that the knowledge delivered by the teacher can be received effectively. Therefore, by using this MOOC platform can help students in improving performance and achievement in learning.

\section{REFERENCE}

Abdullah, M. R. T. (2010). Cabaran integrasi antara kaum di Malaysia : perspektif sejarah, keluarga dan pendidikan. Jurnal Hadhari, 2(1), 61-84. Retrieved from http://journalarticle.ukm.my/248/

Abidin, Z. (2014). Garis panduan amalan terbaik konsep pembelajaran tradun bagi politeknik-politeknik Malaysia. 73. kes pelajar tahun 4SPI, 107.

Anggraini, V. D., Mukhadis, A., \& Muladi. (2013). Problem based learning, motivasi belajar, kemampuan awal, dan hasil belajar siswa SMK. Jurnal Ilmu Pendidikan, 19(2), 187-195. Retrieved from

http://journal.um.ac.id/index.php/jip/arti cle/view/4211/1198

Aris, N. S., \& Halim, F. H. A. (2016). Persepsi pengguna terhadap pembelian secara atas talian. Journal on Technical and Vocational Education, 1(2).

Retrieved from http://upikpolimas.edu.my/ojs/index.php /JTVE/article/view/67

Arsyad, A. (2008). Media pembelajaran. Jakarta: PT. Raja Grafindo Persada.

Arsyad, A. (2011). Media pembelajaran. Jakarta: PT Raja Grafindo Persada.

Aziz, A. Bin, Ramli, N. B., \& Othman, A. Bin. (2014). Pendidikan umum dan TVET. Retrieved from www.slideshare.net/afinde/pendidikanumum-dan-tvet

Bakar, N. A., \& Latif, H. (2010). ESL students feedback on the use of blogs for language learning. $3 \mathrm{~L}$ : Language, Lingusitics, Literature, 16(1). Retrieved from http://ejournal.ukm.my/31/article/view/1 008

Bell, S. (2010). Project-based learning for the 21st century: skills for the future. The Clearing House: A Journal of Educational Strategies, Issues and Ideas, 83(2), 39-43. https://doi.org/10.1080/00098650903505 415

Csikszentmihalyi, M., \& Larson, R. (2014). Validity and reliability of the experience-sampling method. In Flow and the Foundations of Positive Psychology (pp. 35-54). Dordrecht: 
Springer Netherlands. https://doi.org/10.1007/978-94-0179088-8_3

Davis, A. L. (2013). Using instructional design principles to develop effective information literacy instruction: The ADDIE model. College \& Research Libraries News, 74(4), 205-207. https://doi.org/10.5860/crln.74.4.8934

Gan, B., Menkhoff, T., \& Smith, R. (2015). Enhancing students' learning process through interactive digital media: New opportunities for collaborative learning. Computers in Human Behavior, 51, Part $B, 652-663$.

https://doi.org/http://dx.doi.org/10.1016/ j.chb.2014.12.048

Ghafar, M. N. A. (2003). Penyelidikan Pendidikan. Skudai: UTM.

Goodman, L. A. (2011). Comment: on respondent-driven sampling and snowball sampling in hard-to-reach populations and snowball sampling not in hard-to-reach populations.

Sociological Methodology, 41(1), 347353. https://doi.org/10.1111/j.14679531.2011.01242.X

Halim, T. Y. F., MacLaren, A., Romanish, M. T., Gold, M. J., McNagny, K. M., \& Takei, F. (2012). Retinoic-acid-receptorrelated orphan nuclear receptor alpha Is required for natural helper cell development and allergic inflammation. Immunity, 37(3), 463-474. https://doi.org/10.1016/j.immuni.2012.0 6.012

Hardyanto, R. H., \& Surjono, H. D. (2016). Pengembangan dan implementasi elearning menggunakan moodle dan vicon untuk pelajaran pemrograman web di SMK. Jurnal Pendidikan Vokasi, 6(1), 43. https://doi.org/10.21831/jpv.v6i1.6675

Hew, K. F. (2016). Promoting engagement in online courses: What strategies can we learn from three highly rated MOOCS. British Journal of Educational Technology, 47(2), 320-341. https://doi.org/10.1111/bjet.12235

Hishamuddin, F. B. (1987). Model ADDIE.
Retrieved from

http://eprints.utm.my/id/eprint/26224/1/ Model ADDIE.pdf

Ibrahim, J. A. Bin. (2015). Kesan pemadanan antara persembahan multimedia dengan gaya pembelajaran pada laman web adaptif terhadap tahap penguasaan dan kepuasan pelajar kejuruteraan elektrik. Thesis: Fakulti Pendidikan Teknikal dan Vokasional Universiti Tun Hussein Onn Malaysia.

Insyasiska, D., Zubaidah, S., \& Susilo, H. (2015). Pengaruh project based learning terhadap motivasi belajar, kreativitas, kemampuan berpikir kritis, dan kemampuan kognitif siswa pada pembelajaran biologi. Jurnal Pendidikan Biologi, 7(7). Retrieved from http://journal2.um.ac.id/index.php/jpb/ar ticle/view/713

Ismail, I. M. Bin. (2005). Pembangunan dan pengujian prototaip pembelajaran mobile berasaskan prestasi (mobicad) dalam kursus reka bentuk berbantu komputer (CAD). Tesis: Fakulti Pendidikan Universiti Kebangsaan Malaysia.

Ismail, M. E., Hashim, S., Ismail, I. M., Ismail, A., Razali, N., Daud, K. A. M., \& Khairudin, M. (2018). Penggunaan massive open online course (MOOC) dalam kalangan pelajar vokasional [The use of massive open online course (MOOC) among vocational students]. Journal of Nusantara Studies (JONUS), 3(1), 30-41. Retrieved from https://journal.unisza.edu.my/jonus/inde x.php/jonus/article/view/215/78

Karsidi, R. (2013). Peningkatan mutu pendidikan melalui penerapan teknologi belajar jarak jauh. In Seminar Regional Unit Pelaksana Belajar Jarak Jauh. Universitas Terbuka.

Kop, R., \& Carroll, F. (2011). Cloud computing and creativity: learning on a massive open online course. European Journal of Open, Distance and ELearning. Retrieved from $\mathrm{http} / / / \mathrm{www}$.eurodl.org/?p=special\&sp=a rticles\&article $=457$

Lee, Y.-H., Hsieh, Y.-C., \& Hsu, C.-N. 
(2011). Adding innovation diffusion theory to the technology acceptance model: supporting employees' intentions to use e-learning systems. Educational Technology \& Society, 14(4), 124-137. Retrieved from https://eric.ed.gov/?id=EJ963285

Manaf, S. Z. A., Din, R., Hamdan, A., Salleh, N. S. M., Kamsin, I. F., \& Aziz, J. A. (2015). Penggunaan komputer dan internet web 2.0 dalamkalangan generasi y pelajar universiti (the usage ofcomputers and internet web 2.0 in generation yamong university students). Journal of Advanced Research Design, 7(7), 10-18.

Minghat, A. D., Yasin, R. M., Subari, K., \& Noordin, M. K. (2013). Strategi kelesterian pembangunan pendidikan teknikal dan vokasional. In International Seminar on Quality and Affordable Education (ISQAE 2013) (p. 493-504.).

Mohamad, R., \& Shariff, S. B. M. (2011). Kesan penggunaan laman sosial ke atas kaedah perbincangan didalam pengajaran dan pembelajaran mata pelajaran sejarah. Jurnal Teknologi Pendidikan Malaysia, 1(1).

Nordin, N., Norman, H., \& Embi, M. A. (2016). Technology acceptance of massive open online courses in Malaysia. Malaysian Journal of Distance Education, 17(2), 1-16. https://doi.org/10.21315/mjde2015.17.2. 1

Nusir, S., Alsmadi, I., Al-Kabi, M., \& Sharadgah, F. (2012). Studying the impact of using multimedia interactive programs at children ability to learn basic math skills. Acta Didactica Napocensia, 5(2), 17-32. Retrieved from https://files.eric.ed.gov/fulltext/EJ10543 02.pdf

Osman, O. (2016). Merialisasikan universiti global. In APEX 2020 (pp. 1-74).

Retrieved from http://www.eng.usm.my/index.php/ms/m ore-articles/211-perutusan-nc-2016apex-2020-merealisasikan-universitiglobal

Othman, N., \& Mohamad, K. A. (2014).
Thinking skill education and transformational progress in Malaysia. International Education Studies, 7(4). Retrieved from http://www.ccsenet.org/journal/index.ph p/ies/article/view/31934

Pappano, L. (2012, November). The year of the MOOC. New York Times. Retrieved from https://www.nytimes.com/2012/11/04/ed ucation/edlife/massive-open-onlinecourses-are-multiplying-at-a-rapidpace.html

Penny, W. D., Friston, K. J., Ashburner, J. T., Kiebel, S. J., \& Nichols, T. E. (2011). Statistical parametic mapping: the analysis of functional brain image. Retrieved from https://books.google.com/books?hl=en\& $\mathrm{l} r=\& \mathrm{id}=\mathrm{G} \_\mathrm{qdEsDlkp0C} \&$ oi=fnd\&pg $=\mathrm{P}$ $\mathrm{P} 1+\&$ ots $=\mathrm{X} 15 \mathrm{LCzP} 1 \mathrm{UD} \& \mathrm{sig}=\mathrm{ZmWZhr}$ 5EcWbUkf511dQOEvg33mw

Prastiyo, W., Djohar, A., \& Purnawan, P. (2018). Development of Youtube integrated google classroom based elearning media for the light-weight vehicle engineering vocational high school. Jurnal Pendidikan Vokasi, 8(1), 53.

https://doi.org/10.21831/jpv.v8i1.17356

Priyanto, P., Sofyan, H., \& Surjono, H. D. (2017). The determinats of e-learning usage by teachers of vocational high schools in the Yogyakarta Special Region. Jurnal Pendidikan Vokasi, 7(1), 1. https://doi.org/10.21831/jpv.v7i1.12770

Richey, R. C., \& Klein, J. D. (2014). Design and development research. In Handbook of Research on Educational Communications and Technology (pp. 141-150). New York: Springer New York. https://doi.org/10.1007/978-14614-3185-5_12

Schunk, D. H., Meece, J. R., \& Pintrich, P. R. (2013). Motivation in education: theory, research, and applications (4th ed.). Upper Saddle River, N.J.: Pearson/Merrill Prentice Hall.

Sharif, N. B. M. (2012). Kesan penggunaan multimedia dalam kalangan pelajar 
politeknik yang berbeza gaya kognitif. (Doctoral dissertation, Universiti Tun Hussein Onn Malaysia.

Suryadi, A. (2007). Pemanfaatan ICT dalam pembelajaran. Jurnal Pendidikan Terbuka Dan Jarak Jauh, 8(3), 83-96. Retrieved from http://simpen.lppm.ut.ac.id/ptjj/PTJJ Vol 8.2 september 2007/01-acesuryadi.pdf

Tessier, D., Sarrazin, P., \& Ntoumanis, N. (2010). The effect of an intervention to improve newly qualified teachers' interpersonal style, students motivation and psychological need satisfaction in sport-based physical education.

Contemporary Educational Psychology, 35(4), 242-253.

https://doi.org/10.1016/j.cedpsych.2010. 05.005

Thomas, L., Buckland, S. T., Rexstad, E. A., Laake, J. L., Strindberg, S., Hedley, S. L., ... Burnham, K. P. (2010). Distance software: design and analysis of distance sampling surveys for estimating population size. Journal of Applied Ecology, 47(1), 5-14.

https://doi.org/10.1111/j.1365-

2664.2009.01737.x

Vaibhav, A., \& Gupta, P. (2014).

Gamification of MOOCs for increasing user engagement. In 2014 IEEE

International Conference on MOOC, Innovation and Technology in Education (MITE) (pp. 290-295). IEEE. https://doi.org/10.1109/MITE.2014.7020 290

Williams, K. C., \& Williams, C. C. (2011). Five key ingredients for improving student motivation. Research in Higher Education Journal, 11. Retrieved from http://aabri.com/manuscripts/11834.pdf

Yahya, D. A. (2013). MOOC : suatu inovasi P\&P. Buletin Sokongan Penyelidikan \& Pendidikan PTM. Retrieved from http://spaj.ukm.my/ptm/index.php/buleti nspp/article/download/50/26 